\title{
Incidence of gonococcal and chlamydial infections and coverage of two laboratory surveillance networks, France, 2012
}

G La Ruche (guylaruche@hotmail.com)1, Y Le Strat ${ }^{1}$, M Fromage², B Berçot ${ }^{3}$, A Goubard ${ }^{4}$, B de Barbeyrac ${ }^{5}$, P Sednaoui ${ }^{4}$, E Cambau ${ }^{3}$, L Lot $^{1}$

1. French Institute for Public Heath Surveillance (InVS), Department of infectious diseases, Saint-Maurice, France

2. French National Agency for Medicines and Health Products Safety (ANSM), Division for diagnosis, medical devices and equipment. Department of medical devices for diagnosis, radiotherapy and softwares, Saint-Denis, France

3. National Reference associated Laboratory for gonorrhoea, AP-HP, Laboratory of Bacteriology-Virology and Hygiene, Saint Louis-Lariboisière-Fernand Widal hospitals; IAME, UMR 1137, INSERM; Paris Diderot University, Sorbonne Paris Cité, Paris, France

4. National Reference Laboratory for gonorrhoea, Institut Alfred Fournier, Paris, France

5. National Reference Laboratory for Chlamydiae, University of Bordeaux, Bordeaux, France

Citation style for this article:

La Ruche G, Le Strat Y, Fromage M, Berçot B, Goubard A, de Barbeyrac B, Sednaoui P, Cambau E, Lot F. Incidence of gonococcal and chlamydial infections and coverage of two laboratory surveillance networks, France, 2012. Euro Surveill. 2015;20(32):pii=21205. Available online: http://www.eurosurveillance.org/

ViewArticle.aspx?Articleld $=21205$

Article submitted on 15 September 2014 / published on 13 August 2015

Surveillance of sexually transmitted diseases in France is based on voluntary networks of laboratories and clinicians. Despite the importance of incidence data in improving knowledge about the national context and in international comparisons, such data were not previously available. During nationwide quality control of laboratories, mandatory for all laboratories, we conducted a survey in June 2013 to estimate the incidence rates of gonococcal and chlamydial infections for 2012 and to estimate the proportion of diagnoses performed (coverage) by the country's two laboratory-based sentinel networks for these diseases. Estimated incidence rates for 2012 were 39 per 100,000 persons aged 15 to 59 years for gonorrhoea and 257 per 100,000 persons aged 15 to 49 years for chlamydia. These rates were consistent with the average levels for a group of other Western countries. However, different estimates between countries may reflect disparate sources of surveillance data and diverse screening strategies. Better comparability between countries requires harmonising data sources and the presentation of results. Estimated coverage rates of the gonococcal and chlamydial infection surveillance networks in France in 2012 were $23 \%$ and $18 \%$, respectively, with substantial regional variations. These variations justify improving the representativeness of these networks by adding laboratories in insufficiently covered areas.

\section{Introduction}

Sexually transmitted infections (STIS) are a public health issue because of their frequency, the risk of sequelae (e.g. infertility) and transmission of human immunodeficiency virus [1]. The World Health Organization estimates that ca 450 million new cases of curable STIs (gonorrhoea, syphilis, chlamydia and trichomoniasis) occur annually worldwide [2]. The burden of these diseases is often underestimated as asymptomatic cases are likely to be undiagnosed and therefore remain untreated.

In France, the epidemiology of STIs has evolved considerably over the past two decades as a result of a rise in chlamydial infections and gonorrhoea since the end of the 1990 [3], a resurgence of early syphilis since 2000 $[4,5]$ and the emergence of rectal lymphogranuloma venereum since 2002 [6].

Surveillance of STIs is based on voluntary networks of clinicians and public and private laboratories located throughout metropolitan France. Since 1986, gonococcal infections have been monitored by the Renago network (national laboratory network of gonorrhoea) [3,7]. Since the beginning of the 2000s, the annual number of gonococcal infections in men and women reported by this network has increased gradually. This increase has been due both to a real increase in infections and, since 2009, a sharp increase in the use of a nucleic acid amplification test (NAAT) to diagnose gonorrhoea. The surveillance of chlamydial infections has been performed since 1989 through the Renachla network (national laboratory network of chlamydia) [8]. Since 1997, the annual number of reported chlamydial infections by the Renachla network has increased gradually in men and women. This increase in asymptomatic cases is higher than in symptomatic cases for both sexes [9], reflecting increased screening with NAAT [8]. 
TABLE 1

Incidence rate of gonococcal infections by geographical area, ANSM-InVS survey, France, 2012 ( $\mathrm{n}=12,833$ positive tests)

\begin{tabular}{|c|c|c|c|c|}
\hline Geographical area & $\begin{array}{c}\text { Reported } \\
\text { number of cases }\end{array}$ & $\begin{array}{l}\text { Estimated number } \\
\text { of cases }(95 \% \mathrm{Cl})\end{array}$ & $\begin{array}{l}\text { Population } \\
15-59 \text { years }^{\mathrm{a}}\end{array}$ & $\begin{array}{l}\text { Estimated incidence } \\
\operatorname{rate}^{\mathrm{b}}(95 \% \mathrm{Cl})\end{array}$ \\
\hline Paris area $^{c}$ & 4,836 & $\begin{array}{c}5,472 \\
(4,785-6,159) \\
\end{array}$ & $7,363,127$ & $\begin{array}{c}72.8 \\
(63.7-82.0) \\
\end{array}$ \\
\hline North-west area & 1,970 & $\begin{array}{c}2,237 \\
(2,013-2,463)\end{array}$ & $7,171,146$ & $\begin{array}{c}30.6 \\
(27.5-33.7)\end{array}$ \\
\hline North-east area & 1,705 & $\begin{array}{c}2,013 \\
(1,648-2,378)\end{array}$ & $8,304,229$ & $\begin{array}{c}23.8 \\
(19.4-28.1) \\
\end{array}$ \\
\hline South-east area ${ }^{c}$ & 1,991 & $\begin{array}{c}2,479 \\
(2,097-2,861) \\
\end{array}$ & $8,900,793$ & $\begin{array}{c}27.3 \\
(23.1-31.5) \\
\end{array}$ \\
\hline South-west area & 1,287 & $\begin{array}{c}1,503 \\
(1,270-1,736)\end{array}$ & $4,889,397$ & $\begin{array}{c}30.1 \\
(25.4-34.8)\end{array}$ \\
\hline Total Metropolitan France & 11,968 & $\begin{array}{c}13,951 \\
(13,007-14,895) \\
\end{array}$ & $36,628,692$ & $\begin{array}{c}37.3 \\
(34.8-39.9)\end{array}$ \\
\hline French West Indies-French Guiana & 353 & $\begin{array}{c}495 \\
(393-596) \\
\end{array}$ & 605,245 & $\begin{array}{c}80.1 \\
(63.7-96.5) \\
\end{array}$ \\
\hline Reunion Island-Mayotte & 512 & $\begin{array}{c}621 \\
(445-798) \\
\end{array}$ & 632,279 & $\begin{array}{c}96.3 \\
(68.9-123.6) \\
\end{array}$ \\
\hline French overseas departments & 865 & $\begin{array}{c}1,116 \\
(935-1,297) \\
\end{array}$ & $1,237,524$ & $\begin{array}{c}88.4 \\
(74.0-102.7) \\
\end{array}$ \\
\hline Total France & 12,833 & $\begin{array}{c}15,067 \\
(14,105-16,028)\end{array}$ & $37,866,216$ & $\begin{array}{c}39.0 \\
(36.5-41.5)\end{array}$ \\
\hline
\end{tabular}

ANSM: French National Agency for Medicines and Health Products Safety; $\mathrm{CI}$ : confidence interval; InVS: Institut de Veille Sanitaire.

a As of 1 January 2013. Census data updated in January 2014 [12].

b Per 100,000 persons aged 15 to 59 years.

c Excluding two private laboratories, one in the Paris area and another in the south-east area, which operate at a national level. Their data are included in the metropolitan and total results.

The two networks were set up and are managed by the French Institute for Public Health Surveillance (InVS). Participation of laboratories in the networks is on a voluntary basis, without special benefit apart from obtaining, for about half of the laboratories of Renago network, the results of susceptibility tests performed on the gonococcal strains. In 2012, respectively 202 and 70 laboratories participated in the Renago and Renachla networks (among them, 37 laboratories were part of both networks). Data collected from these two surveillance systems are used to estimate the evolution over time of gonococcal and chlamydial infections.

To complement this sentinel surveillance, it is essential to have incidence data in order to improve knowledge of the national context and for the purpose of international comparisons. French data on the incidence of STIs have not been available until the present work. Furthermore, French data on the prevalence of STIs are limited. The only national survey studying the prevalence of chlamydial infection in the general population (NatChla survey) was conducted in 2006 and estimated a prevalence of $1.6 \%$ and $1.4 \%$, respectively, in women and men aged between 18 and 44 years, and of $3.2 \%$ and $2.5 \%$, respectively, in women and men between 18 and 29 years $[10,11]$. During nationwide quality control of laboratories in June 2013 , we conducted a survey to estimate the incidence of gonococcal and chlamydial infections in France for 2012 and the proportion of diagnoses performed by our two laboratory surveillance networks (for the purposes of this manuscript referred to as 'coverage').

\section{Methods}

The French National Agency for Medicines and Health Products Safety (ANSM) is responsible for national quality control of medical laboratories. It uses external quality assessment (EQA) programmes covering all laboratory disciplines, including bacteriology. Registration and participation of laboratories for quality control are mandatory. In June 2013, an EQA survey was performed involving the 1,399 registered bacteriology laboratories: 1,335 located in metropolitan France and 64 in the French overseas departments (FODs). FODs include the French West Indies (Guadeloupe and Martinique) and French Guiana in the Americas, and Reunion Island and Mayotte in the Indian Ocean. Each laboratory received a strain of Neisseria gonorrhoeae to perform susceptibility testing. By agreement between the ANSM and the InVS, a short questionnaire on the activity of laboratories on gonococcal and chlamydial diagnoses was added. For each laboratory in metropolitan France and the FODs, we recorded the number of gonococcal infections diagnosed by culture and by NAAT, and the number of chlamydial urogenital infections diagnosed by NAAT from 1 January to 31 December 2012. A positive 
TABLE 2

Incidence rate of chlamydial infection by geographical area, ANSM-InVS survey, France, 2012 ( $\mathrm{n}=58,155$ reported cases)

\begin{tabular}{|c|c|c|c|c|}
\hline Geographical area & $\begin{array}{c}\text { Reported number } \\
\text { of cases }\end{array}$ & $\begin{array}{l}\text { Estimated number } \\
\text { of cases }(95 \% \mathrm{Cl})\end{array}$ & Population $15-49$ years $^{a}$ & $\begin{array}{l}\text { Estimated incidence } \\
\quad \text { rate }^{\mathrm{b}}(95 \% \mathrm{Cl})\end{array}$ \\
\hline Paris area ${ }^{c}$ & 12,985 & $\begin{array}{c}17,312 \\
(12,658-21,965)\end{array}$ & $5,900,616$ & $\begin{array}{c}288 \\
(210-365)\end{array}$ \\
\hline North-west area & 6,395 & $\begin{array}{c}7,687 \\
(5,846-9,528)\end{array}$ & $5,473,758$ & $\begin{array}{c}138 \\
(105-171)\end{array}$ \\
\hline North-east area & 6,217 & $\begin{array}{c}7,770 \\
(5,058-10,482)\end{array}$ & $6,384,158$ & $\begin{array}{c}119 \\
(78-161) \\
\end{array}$ \\
\hline South-east area ${ }^{c}$ & 10,497 & $\begin{array}{c}12,049 \\
(491-23,608) \\
\end{array}$ & $6,869,673$ & $\begin{array}{c}172 \\
(7-338) \\
\end{array}$ \\
\hline South-west area & 3,915 & $\begin{array}{c}4,753 \\
(2,913-6,594) \\
\end{array}$ & $3,704,377$ & $\begin{array}{c}126 \\
(77-174) \\
\end{array}$ \\
\hline Total Metropolitan France & 54,051 & $\begin{array}{c}71,657 \\
(41,522-101,792)\end{array}$ & $28,332,582$ & $\begin{array}{c}249 \\
(144-352)\end{array}$ \\
\hline French West Indies-French Guiana & 2,529 & $\begin{array}{c}3,367 \\
(1,099-5,635) \\
\end{array}$ & 467,288 & $\begin{array}{c}706 \\
(231-1,182) \\
\end{array}$ \\
\hline Reunion Island-Mayotte & 1,575 & $\begin{array}{c}1,895 \\
(247-3,542) \\
\end{array}$ & 519,708 & $\begin{array}{c}357 \\
(47-668) \\
\end{array}$ \\
\hline French overseas departments & 4,104 & $\begin{array}{c}5,261 \\
(2,996-7,527) \\
\end{array}$ & 986,996 & $\begin{array}{c}522 \\
(297-747) \\
\end{array}$ \\
\hline Total France & 58,155 & $\begin{array}{c}76,918 \\
(46,711-107,126)\end{array}$ & $29,319,578$ & $\begin{array}{c}257 \\
(156-358)\end{array}$ \\
\hline
\end{tabular}

ANSM: French National Agency for Medicines and Health Products Safety; CI: confidence interval; InVS: Institut de Veille Sanitaire.

a As of 1 January 2013. Census data updated in January 2014 [12].

${ }^{b}$ Per 100,000 persons aged 15 to 49 years.

c Excluding two private laboratories, one in the Paris area and another in the south-east area, which operate at a national level. Their data are included in the metropolitan and total results.

culture or a positive NAAT defined gonococcal infection while a positive NAAT defined chlamydial infection. The survey did not collect data on individual characteristics (age, sex, reason for testing etc). The number of tests performed was not collected; therefore the proportion of positive samples is unknown. Here we report only the results of the questionnaire-based survey, not the quality control susceptibility testing results.

In France, as a result of new regulations for medical laboratories, multi-site laboratories are becoming more common, i.e. groups of laboratories which remain urogenital sampling sites but centralise their bacteriological activity on one of the sites. For those laboratories, quality control and the questionnaire-based survey were performed with the specific laboratory's administrative structure providing combined information for all its sites using a single questionnaire for the whole group.

\section{Estimation of the total number of gonococcal} and chlamydial infections diagnosed in France in 2012

To estimate the total number of gonococcal and chlamydial infections diagnosed by all French laboratories, we built 67 strata by crossing, when possible, each geographical area with each sector of activity (private or public). We then assumed that infection diagnosis activity (i.e. the proportion of laboratories performing tests and the number of diagnosed infections) within each stratum was the same for non-respondent laboratories (i.e. laboratories not replying to calls for quality control checks, laboratories providing no information on the availability of tests, and laboratories not specifying the number of diagnosed infections) as for their responding counterparts. We assigned a sampling weight to each laboratory for all estimates. These weights were equal to the inverse of the participation rates observed in each stratum. Variances were estimated using Taylor linearisation.

For gonococcal infections, we were not able to identify the number of diagnoses made using NAAT and culture tests simultaneously for the same patient in each laboratory at the national level. These data were available however for the laboratories in the Renago network. Among private laboratories of the network where both NAAT and culture tests were available in 2012, 41\% of gonococcal infections $(444 / 1,072)$ were diagnosed using both techniques simultaneously. This percentage was $18 \%(119 / 644)$ in the public sector. Consequently, in order to estimate the total number of gonococcal infections diagnosed by using both techniques simultaneously in all French public and private laboratories, we applied the Renago network's percentages. Within the Renago network, nearly $98 \%$ of cases of patients 
Coverage of the Renago network for gonococcal infections, by geographical area and sector of activity, ANSM-InVS survey, metropolitan France, 2012 ( $\mathrm{n}=3,276$ cases)

\begin{tabular}{|c|c|c|c|c|c|}
\hline & \multicolumn{2}{|c|}{$\begin{array}{l}\text { Renago network } \\
\text { (InVS data) }\end{array}$} & \multicolumn{2}{|c|}{$\begin{array}{c}\text { All laboratories } \\
\text { (ANSM-InVS survey) }\end{array}$} & \multirow{2}{*}{$\begin{array}{l}\text { Coverage }(\mathrm{A} / \mathrm{B}) \\
(95 \% \mathrm{Cl})\end{array}$} \\
\hline & $\begin{array}{l}\text { Number of } \\
\text { laboratories }\end{array}$ & $\begin{array}{l}\text { Number of } \\
\text { cases }(A)\end{array}$ & $\begin{array}{l}\text { Number of } \\
\text { laboratories }\end{array}$ & $\begin{array}{c}\text { Estimated number } \\
\text { of cases }(B)\end{array}$ & \\
\hline \multicolumn{6}{|l|}{ Geographical area } \\
\hline Paris area & 22 & 1,060 & $254^{a}$ & 5,472 & $19.4 \%(16.9-21.8)$ \\
\hline North-west area & 38 & 708 & 205 & 2,238 & $31.6 \%(28.5-34.8)$ \\
\hline North-east area & 34 & 498 & 232 & 2,013 & $24.7 \%(20.3-29.2)$ \\
\hline South-east area & 33 & 541 & $266^{a}$ & 2,479 & $21.8 \%(18.5-25.2)$ \\
\hline South-west area & 23 & 469 & 149 & 1,503 & $31.2 \%(26.4-36.0)$ \\
\hline Total Metropolitan France & 150 & 3,276 & 1,108 & 13,951 & $23.5 \%(21.9-25.1)$ \\
\hline \multicolumn{6}{|l|}{ Sector of activity } \\
\hline Public laboratories & 37 & 911 & 319 & 4,058 & $22.4 \%(20.4-24.5)$ \\
\hline Private laboratories & 113 & 2,365 & 789 & 9,893 & $23.9 \%(21.8-26.0)$ \\
\hline
\end{tabular}

ANSM: French National Agency for Medicines and Health Products Safety; CI: confidence interval; InVS: Institut de Veille Sanitaire.

a Excluding two private laboratories, one in the Paris area and another in the south-east area, which operate at a national level. Their data are included in the metropolitan results.

with gonococcal infections were aged 15 to $59(97.5 \%$ in $2010,97.8 \%$ in 2011 and 2012). We therefore also assumed that $98 \%$ of gonococcal cases reported by all French laboratories were in this age group. Similarly, ca $98 \%$ of cases of chlamydial infections reported within the Renachla network concerned patients aged 15 to 49 (98.2\% in 2010 and 2011, 98.1\% in 2012). Accordingly, we assumed that $98 \%$ of chlamydial cases reported by all French laboratories were in this age group.

\section{Estimation of incidence rates for gonococcal} and chlamydial infections in France in 2012 The estimated national incidence rate for each infection type equalled the total estimated number of infections diagnosed in 2012 divided by the size of the population aged 15 to 59 for gonococcal infections and aged 15 to 49 for chlamydial infections. National census data of the French population estimated on 1 January 2013 were used to evaluate both population sizes [12]. For Mayotte, the age distribution of the 2007 census [13] is extrapolated to the 2012 population census [14]. Incidence rates and their 95\% confidence intervals (Cls) were also estimated for each of the five areas in metropolitan France defined by telephone area codes (01, 02, 03, 04 and 05) and for the FODs (differentiating areas in the Americas and in the Indian Ocean). Unlike other laboratories which receive local specimens, two private laboratories, one located in the Paris area (01) and the other in the south-east area (04), received specimens from all over France and were therefore excluded from regional calculations.
Estimation of coverage of Renago and Renachla networks in metropolitan France

Gonococcal and chlamydial infections are reported on a continuous basis by the two sentinel networks to the InVS. The coverage of the two networks in 2012 was estimated by dividing the number of infections these networks reported during 2012 by the estimated total number of gonococcal and chlamydial infections diagnosed in all laboratories in metropolitan France. Coverage rates and their $95 \% \mathrm{Cls}$ were also estimated for each of the five areas and according to whether laboratories were in the public or private sector. All statistical analyses were performed using Stata v.12.1 software.

\section{Results}

Characteristics of French laboratories and participation in quality control

Of the 1,399 French bacteriology laboratories, 921 (66\%) were based in one site while 478 (34\%) were multi-site. Almost half of the private laboratories were multi-site $(477 / 1,033 ; 46 \%)$. Conversely, only one public laboratory was multi-site $(1 / 366:<1 \%)$. The 1,399 laboratories consisted of a total of 4,057 sites $(3,942$ in metropolitan France and 115 in the FODs). Among multi-site laboratories, the median number of sites was 5 (range: $2-60$ ).

The rate of participation in quality control was only $96 \%(1,342 / 1,399)$ despite its mandatory nature. Among the 1,342 respondent laboratories, 1,279 (938 private and 341 public) were located in metropolitan 
Coverage of Renachla network for chlamydial infections, by geographical area and sector of activity, ANSM-InVS survey, metropolitan France, 2012 ( $\mathrm{n}=13,074$ cases)

\begin{tabular}{|c|c|c|c|c|c|}
\hline & \multicolumn{2}{|c|}{$\begin{array}{l}\text { Renachla network } \\
\text { (InVS data) }\end{array}$} & \multicolumn{2}{|c|}{$\begin{array}{c}\text { All laboratories } \\
\text { (ANSM-InVS survey) }\end{array}$} & \multirow{2}{*}{$\begin{array}{l}\text { Coverage }(\mathrm{A} / \mathrm{B}) \\
(95 \% \mathrm{Cl})\end{array}$} \\
\hline & $\begin{array}{l}\text { Number of } \\
\text { laboratories }\end{array}$ & $\begin{array}{l}\text { Number of } \\
\text { cases }(A)\end{array}$ & $\begin{array}{l}\text { Number of } \\
\text { laboratories }\end{array}$ & $\begin{array}{c}\text { Estimated number } \\
\text { of cases (B) }\end{array}$ & \\
\hline \multicolumn{6}{|l|}{ Geographical area } \\
\hline Paris area & 11 & 3,719 & $96^{a}$ & 17,312 & $21.5 \%(15.7-27.2)$ \\
\hline North-west area & 12 & 1,961 & 48 & 7,687 & $25.5 \%(19.4-31.6)$ \\
\hline North-east area & 11 & 2,065 & 46 & 7,770 & $26.6 \%(17.4-35.8)$ \\
\hline South-east area & 7 & 3,016 & $36^{a}$ & 12,049 & $25.0 \%(1.2-48.9)$ \\
\hline South-west area & 11 & 2,313 & 42 & 4,753 & $48.7 \%(29.9-67.4)$ \\
\hline Total Metropolitan France & 52 & 13,074 & 270 & 71,657 & $18.2 \%(10.6-25.9)$ \\
\hline \multicolumn{6}{|l|}{ Sector of activity } \\
\hline Public laboratories & 26 & 5,389 & 92 & 20,848 & $25.8 \%(11.6-40.1)$ \\
\hline Private laboratories & 25 & 7,685 & 178 & 50,809 & $15.1 \%(6.9-23.4)$ \\
\hline
\end{tabular}

ANSM: French National Agency for Medicines and Health Products Safety; CI: confidence interval; InVS: Institut de Veille Sanitaire.

a Excluding two private laboratories, one in the Paris area and another in the south-east area, which operate at a national level. Their data are included in the metropolitan results.

France and 63 (49 private and 14 public) in the FODs. The response rate by private and public laboratories was similar between metropolitan France and the FODs, and between the five metropolitan areas. Of the 1,342 laboratories participating in quality control, 127 (9\%) did not answer the additional questionnaire about their activity.

\section{Estimated number of diagnoses and incidence} rate of gonococcal infections in France in 2012 Of the 1,342 laboratories which participated in quality control, 1,147 (85\%) reported performing gonococcal cultures in the laboratory or, in the case of multi-site laboratories, in at least one laboratory site. Sixty-three (5\%) laboratories declared that they did not perform this test and 132 (10\%) did not answer this question. Among the 1,147 laboratories performing cultures, $1,061(93 \%)$ indicated the number of positive specimens diagnosed in 2012: a total of 8,820 positive specimens $(8,235$ in metropolitan France and 585 in the FODs). The average number of positive specimens per laboratory was higher in the FODs than in metropolitan France (14.3 (range: 0-207) vs 8.1 (range: 0-114); $\mathrm{p}$ <0.001) and slightly higher in private than in public laboratories (8.5 (range: 0-207) vs 7.9 (range 0-178); $\mathrm{p}$ <.001). In metropolitan France, taking into account the number of sites, an average of 2.6 positive specimens per site were diagnosed in 2012.

Of the 1,342 respondent laboratories, 111 (8\%) reported performing NAAT for gonococcal infections in the laboratory or, in the case of multi-site laboratories, in at least one laboratory site. In addition, 1,092 (81\%) declared they did not perform this test and 139 (10\%) did not answer this question. Among the 111 laboratories performing gonococcal infection diagnosis by NAAT, 94 (85\%) indicated the number of diagnoses made in 2012: a total of 4,013 cases of gonococcal infection were diagnosed by NAAT $(3,733$ in metropolitan France and 280 in the FODs). The average number of gonococcal infections diagnosed by NAAT per laboratory was similar between the FODs and metropolitan France ( 35.0 vs $43.4 ; p=0.67$ ), and between private and public laboratories ( 41.1 vs $45.3 ; p=0.90$ ). In metropolitan France, an average of 8.1 cases per site were diagnosed by NAAT in 2012.

Finally, among the 1,342 respondent laboratories, 1,213 (90\%) provided information on gonococcal infection diagnosis by culture or NAAT: 1,042 laboratories (86\%) performed cultures only, six ( $1 \%$ ) performed NAAT only, 105 (9\%) performed both tests and 60 (5\%) did not perform either of the two tests (and accordingly, they did not diagnose any cases). Thus, 95\% $(1,108 / 1,164)$ of the laboratories in metropolitan France and $92 \%(45 / 49)$ in the FODs performed one of the two tests. In 2012 , a total of 12,833 positive tests for gonococcal infection were reported by the 1,069 laboratories (1,027 in metropolitan France and 42 in the FODs) which reported the number of diagnoses they made by culture or NAAT: 11,968 cases in metropolitan France and 865 cases in the FODs.

Table 1 shows the estimated incidence rate of gonococcal infection in France in 2012 at the national level and by geographical area. The overall incidence rate was 
TABLE 5

Incidence rates of gonococcal infections in selected countries, 2012

\begin{tabular}{|c|c|c|c|c|}
\hline Country [reference] & Sources of data & $\begin{array}{l}\text { Incidence rate in } \\
\text { the population }\end{array}$ & Age group (years) & $\begin{array}{l}\text { Incidence rate in } \\
\text { the age group }\end{array}$ \\
\hline United States [16] & $\begin{array}{c}\text { Notifiable diseases, } \\
\text { prevalence studies, } \\
\text { network for STI surveillance, } \\
\text { national surveys }\end{array}$ & 108 & $\begin{array}{l}15-54 \\
15-64\end{array}$ & $\begin{array}{l}191 \\
158\end{array}$ \\
\hline England $[19,20]$ & Genitourinary medicine clinics & 48 & $\begin{array}{l}15-44 \\
15-64\end{array}$ & $\begin{array}{c}108 \\
72\end{array}$ \\
\hline Canada: Quebec [21] & Network of hospital laboratories & 28 & $15-59$ & 44 \\
\hline Sweden [17] & Notification by doctors & 11 & $15-59$ & 19 \\
\hline Belgium [22] & Sentinel network of laboratories & $N A^{b}$ & $15-59$ & 14 \\
\hline France & Bacteriology laboratories & NA & $15-59$ & 39 \\
\hline
\end{tabular}

NA: not available.

a Rates per 100,000 persons. For the recalculation of rates using age data, documents referenced in the first column were used, except for Quebec and Sweden where population estimates were used ([30] and [31], respectively).

${ }^{b}$ Rate in the reference study seems to have been calculated in the age group 15-59 years.

estimated at 39.0 per 100,000 persons aged 15 to 59 years (95\% Cl: $36.5-41.5)$. It was significantly higher in the FODs (88.4 per 100,000 persons aged 15 to 59 years; $95 \% \mathrm{Cl}: 74.0-102.7)$ than in metropolitan France (37.3 per 100,000 persons aged 15 to 59 years; $95 \% \mathrm{Cl}$ : 34.8-39.9). Within metropolitan France, the incidence rate was higher in the Paris area than in the other four areas (Table 1).

\section{Estimated number of diagnoses and incidence} rate of chlamydial infections in France in 2012 Of the 1,342 laboratories who participated in quality control, $290(22 \%)$ reported that they performed NAAT for chlamydial infections in the laboratory or, in the case of multi-site laboratories, in at least one laboratory site. In addition, 912 (68\%) declared they did not perform this test and 140 (10\%) did not answer this question. Among the 290 laboratories which diagnosed chlamydial infections, 255 (88\%) indicated the number of diagnoses in 2012: a total of 58,155 cases of chlamydial infection were diagnosed $(54,051$ in metropolitan France and 4,104 in the FODs). The average number of chlamydial infections per laboratory was not statistically different between the FODs and metropolitan France (216.0 vs 229.0; $p=0.07$ ) or between private and public laboratories (234.8 vs 216.3; $p=0.34$ ). In metropolitan France, an average of 56.9 cases per site were diagnosed in 2012.

Table 2 shows the estimated incidence rate of chlamydial infections in France in 2012 at national level and by geographical area. The overall incidence rate was estimated at 257 per 100,000 persons aged 15 to 49 years (95\% Cl: $156-358)$. As was the case for gonorrhoea, it was higher in the FODs (522 per 100,000 persons aged 15 to 49 years; $95 \% \mathrm{Cl}: 297-747)$ than in metropolitan France (249 per 100,000 persons aged 15 to 49 years; $95 \% \mathrm{Cl}: 144-352)$. Likewise, within metropolitan France the incidence rate was higher in the Paris area than in the other four areas (Table 2).

\section{Characteristics and coverage of the Renago network in metropolitan France in 2012} Of the 1,335 laboratories registered by the ANSM for bacteriology quality control in metropolitan France, 199 (15\%) were part of the Renago network in 2012. Three other laboratories in the Renago network did not participate in quality control that year as they were not registered at the time by the ANSM. The response rate to quality control was not statistically different between laboratories in the Renago network and other metropolitan laboratories ( $98 \%$ vs $95 \% ; p=0.10$ ).

The average number of gonococcal infections diagnosed per laboratory either by culture or NAAT was 3.3 times higher in the Renago network than in other metropolitan laboratories (27.9 vs 8.4 ; p<0.001). Nearly three times more laboratories in the Renago network than in other metropolitan laboratories performed NAAT testing ( $18 \%$ vs $7 \%$; $p<0.001$ ). Multi-site laboratories were more common in the Renago network than in other laboratories ( $55 \%$ vs $32 \%$; $p<0.001$ ). There were on average 5.0 cases per site diagnosed in 2012 in the Renago network compared with 3.3 cases per site in all other metropolitan laboratories. 
TABLE 6

Incidence rates of chlamydial infections in selected countries, 2012

\begin{tabular}{|c|c|c|c|c|}
\hline Country [reference] & Sources of data & $\begin{array}{l}\text { Incidence rate in } \\
\text { the population }^{\mathrm{a}}\end{array}$ & Age group (years) & $\begin{array}{l}\text { Incidence rate in } \\
\text { the age group }\end{array}$ \\
\hline United States [16] & $\begin{array}{c}\text { Notifiable diseases, } \\
\text { prevalence studies, } \\
\text { network for STI surveillance, } \\
\text { national surveys }\end{array}$ & 457 & $\begin{array}{l}15-44 \\
15-54\end{array}$ & $\begin{array}{c}1,091 \\
817\end{array}$ \\
\hline England $[19,23]$ & $\begin{array}{l}\text { Genitourinary medicine and other } \\
\text { community services }\end{array}$ & 390 & $\begin{array}{l}15-44 \\
15-64\end{array}$ & $\begin{array}{l}930 \\
586\end{array}$ \\
\hline Canada: Quebec [21] & Notifiable diseases & 252 & $15-49$ & 528 \\
\hline Sweden [18] & Notification by doctors & 395 & $15-49$ & 866 \\
\hline Belgium [22] & Sentinel network of laboratories & $70^{\mathrm{b}}$ & $15-49$ & 88 \\
\hline France & Bacteriology laboratories & NA & $15-49$ & 257 \\
\hline
\end{tabular}

NA: not available.

a Rates per 100,000 persons. For the recalculation of rates using age data, documents referenced in the first column were used, except for Quebec and Sweden where population estimates were used ([30] and [31], respectively).

${ }^{b}$ Rate in the reference study seems to have been calculated in the age group 15-59 years.

The overall coverage of the Renago network was $23 \%$ (95\% Cl: 22-25\%); coverage in the Paris area (area code 01) was $19 \%$ and lower than in the other four areas (Table 3). Furthermore, coverage rates in the two eastern areas (area codes 03 and 04 ) were ca $23 \%$ and lower than those in the two western areas (area codes 02 and 05 ) with ca 31\%. Coverage by private laboratories $(24 \%)$ was slightly higher than that by their public counterparts (22\%).

\section{Characteristics and coverage of the Renachla} network in metropolitan France in 2012

Of the 1,335 laboratories registered by the ANSM for bacteriology quality control in metropolitan France, $65(5 \%)$ were part of the Renachla network in 2012. Five other laboratories belonging to the Renachla network did not participate in quality control that year as they were not registered at the time by the ANSM. The response rate to the quality control was similar between the Renachla network and other metropolitan laboratories ( $98 \%$ vs $96 \%, p=0.23$ ).

The average number of chlamydial infections diagnosed per laboratory was slightly higher in the Renachla network than in the other metropolitan laboratories (255.9 vs 223.6; $p<0.001)$. The proportion of multi-site laboratories was not different between the Renachla network and other metropolitan laboratories (35\% vs 40\%; $p=0.42)$. On average, 55.3 cases per site were diagnosed in 2012 in the Renachla network compared with 57.3 cases per site in other metropolitan laboratories.
The overall coverage of the Renachla network was $18 \%$ (95\% Cl: $11-26 \%)$. Coverage in the south-west area (area code 05) (49\%) was higher than those of the other four areas (Table 4). Furthermore, regional coverage rates in the north (area codes 02 and 03) of ca $26 \%$ were lower than those in the Paris and south-east areas (ca $29 \%$ each). The coverage of private laboratories was $15 \%$ and lower than that of their public counterparts with $26 \%$.

\section{Discussion}

This study presents, for the first time, estimates of the incidence of gonococcal and chlamydial infections in France from a comprehensive laboratory survey. Incidence rates for 2012 were estimated at 39 per 100,000 persons aged 15 to 59 years for gonococcal infections and at 257 per 100,000 persons aged 15 to 49 years for chlamydial infections. We found disparities for both infections' incidence rates between metropolitan France and the FODs, rates being twice as high in the latter. Differences within metropolitan France were also observed, with the Paris area having higher rates than its four counterparts.

Incidence data help create international comparisons. However, differences in the estimation of incidence rates between countries are difficult to interpret for two major reasons. Firstly, data sources may differ greatly from one country to the next. Such sources include mandatory notification, laboratory data, sentinel networks of laboratories, clinicians etc. Aggregate data from several countries should be used with caution because of the heterogeneity in reporting and 
healthcare systems [15]. Secondly, incidence rates calculated on the basis of the entire population do not give a true picture of reality since only a portion of the population is at risk of STIs. Approximately $98 \%$ of gonococcal and chlamydial infections diagnosed by the two French laboratory networks, Renago and Renachla, affect people aged 15 to 59 years and 15 to 49 years, respectively. Similar age distributions have also been found in other Western countries, for example in the United States (US) [16] and Sweden $[17,18]$. Tables 5 and 6 show the incidence of gonococcal and chlamydial infections in a group of Western countries, after recalculation for specific age groups.

The incidence rate of gonococcal infections estimated for 2012 in France from laboratory data was about four times lower than that in the US, obtained by combining several sources of data [16], about two times lower than that in England $[19,20]$ and close to that in Quebec [21]. However it was two to three times higher than that in Sweden [17] and Belgium [22] (Table 5).

The incidence rate of chlamydial infections estimated for 2012 in France was approximately three times lower than that in the US [16], Sweden [16] and England $[19,23]$, two times lower than that in Quebec [21], but approximately three times higher than that in Belgium [22] (Table 6).

The different estimates between countries may reflect a combination of true differences in incidence, disparate sources of surveillance data and diversity of testing and screening strategies. In particular for chlamydia, screening policies for young adult populations vary in different countries. Availability and affordability of testing are also key issues. In France, only $8 \%$ of laboratories performed NAAT for gonorrhoea because this test is not yet reimbursed by health insurance.

Perennial surveillance of STIs in France is mainly based on sentinel networks, including voluntary laboratory networks. The higher average number of gonococcal infections diagnosed in laboratories in the Renago network than in other metropolitan laboratories reflects the initial selection of active and experienced laboratories in gonococcal culture to join the network when it was first established. The Renago and Renachla networks' coverage rates for 2012 were estimated at $23 \%$ and $18 \%$, respectively, with substantial regional variations. In the coming years, efforts should be made to improve the representativeness of these networks, notably by adding laboratories in some geographical areas (e.g. in the Paris area for gonococcal infection surveillance and in northern France for chlamydial infection surveillance) and balance the regional coverage rates.

\section{Survey limitations}

The incidence rates of gonococcal and chlamydial infections presented here should be considered as underestimations of the true incidence rates in the population.
Biologically confirmed cases represent only a portion of infections for a number of interrelated reasons. A significant proportion of infections are asymptomatic, particularly in women (55 to $95 \%[24,25]$ ) or in cases of extragenital (oral or anal) localisations [26,27], and therefore remain unrecognised. Symptomatic patients do not always consult a doctor. Physicians do not systematically prescribe a microbiological test, whether or not the patients receive presumptive treatment. When tests are prescribed, patients may decide not to go to a laboratory. When tests are performed, they can be negative in infected patients. This is particularly true for gonococcal cultures in women, although the increasing use of NAAT reduces the proportion of false negative tests and allows diagnosis in asymptomatic individuals [28].

Other reasons for underestimation of incidence rates are more specific to the present study. This survey did not account for laboratories that were not recorded in the national process of bacteriology quality control in 2013. However, the number of such laboratories was probably very small, given the compulsory nature of the registration to quality control. Moreover, in the case of multi-site laboratories, it is possible that some central administrative structures may have provided information on gonococcal and chlamydial infections for only a portion of all sites. Finally, regional rates were underestimated due to the exclusion of data from two laboratories active at the national level, where cases had not been assigned to a specific geographic area.

Another limitation of our study is the extrapolation of missing data from respondents. However, our extrapolation seems reasonable insofar as it is unlikely that non-participation in quality control was related to the activity of a laboratory in the diagnosis of gonococcal or chlamydial infections.

\section{Recommendations}

STI surveillance allows us to monitor the trends of these infections and to assess the impact of public policies aiming to control them. Each surveillance system has its advantages, disadvantages and limitations. However, to make indicators comparable between countries, more information on testing policies must be collected and harmonisation is needed. The comparability of the data provided by European countries is not optimal in the absence of standardisation. The European Centre for Disease Prevention and Control recognises the need to improve harmonisation of surveillance systems, case definitions and presentation of data [29]. Based on our study, we recommend for example the use of appropriate age groups to calculate the incidence of gonococcal (15-59 years) and chlamydial (15-49 years) infections to avoid an underestimation of the incidence and ensure comparability of results. 
Acknowledgements

We thank Betty Basselier for the management of the Renago and Renachla networks and for data entry. We thank Jude Sweeney for the English revision and editing of the manuscript. We also thank all the participating laboratories for quality control.

\section{Conflict of interest}

None declared.

\section{Authors' contributions}

GLR conceived and wrote the paper. YLS, MF, BB, AG, BDB, PS, EC and FL participated in the design of the analysis, commented on the first draft of the paper and approved the final version.

\section{References}

1. World Health Organization (WHO). Estimation of the incidence and prevalence of sexually transmitted infections. Report of a WHO consultation, Treviso, Italy, 2002. Geneva: WHO; 2002. Available from: http://www.who.int/hiv/pub/sti/en/ who_hiv_2002_14.pdf

2. World Health Organization (WHO). Emergence of multi-drug resistant Neisseria gonorrhoeae - Threat of global rise in untreatable sexually transmitted infections. Fact sheet. WHO/RHR/11.14. Geneva: WHO; 2011. Available from: http:// whqlibdoc.who.int/hq/2011/WHO_RHR_11.14_eng.pdf

3. Goulet V, Sednaoui P, Laporte A, Billy C, Desenclos JC. The number of gonococcal infections identified by the RENAGO network is increasing. Euro Surveill. 2000;5(1):2-5. PMID:12631875

4. Couturier E, Michel A, Janier M, Dupin N, Semaille C. Syphilis surveillance network. Syphilis surveillance in France, 20002003. Euro Surveill. 2004;9(12):8-10. PMID:15677855

5. Dupin N, Jdid R, N'Guyen YT, Gorin I, Franck N, Escande JP. Syphilis and gonorrhoea in Paris: the return. AIDS. 2001;15(6):814-5. Available from: http://dx.doi. org/10.1097/00002030-200104130-00026 PMID:11371705

6. Herida M, de Barbeyrac B, Sednaoui P, Scieux C, Lemarchand N, Kreplak G, et al. Rectal lymphogranuloma venereum surveillance in France 2004-2005. Euro Surveill. 2006;11(9):155-6. PMID:17075158

7. La Ruche G, Goubard A, Berçot B, Cambau E, Semaille $C$, Sednaoui P. Gonococcal infections and emergence of gonococcal decreased susceptibility to cephalosporins in France, 2001 to 2012. Euro Surveill. 2014;19(34):20885. Available from: http://dx.doi.org/10.2807/1560-7917. ES2014.19.34.20885 PMID:25188611

8. Goulet G, Laurent E, Semaille C, les biologistes du réseau Rénachla. Augmentation du dépistage et des diagnostics d'infections à Chlamydia trachomatis en France: analyse des données Rénachla (2007-2009). [Increased screening and diagnosis of infections with Chlamydia trachomatis in France: an analysis of Renachla data (2007-2009)]. Bull Epidemiol Hebd (Paris). 2011;26-28:316-9. French.

9. La Ruche G, Goulet V, Bouyssou A, Sednaoui P, De Barbeyrac $B$, Dupin N, et al. [Current epidemiology of bacterial STIs in France]. Presse Med. 2013;42(4 Pt 1):432-9. French. http:// dx.doi.org/10.1016/j.lpm.2012.09.022 PMID:23419462

10. Goulet V, de Barbeyrac B, Raherison S, Prudhomme M, Semaille C, Warszawski J, et al. Prevalence of Chlamydia trachomatis: results from the first national population-based survey in France. Sex Transm Infect. 2010;86(4):263-70. Available from: http://dx.doi.org/10.1136/sti.2009.038752 PMID:20660590

11. Goulet V, de Barbeyrac B, Raherison S, Prudhomme M, Velter $A$, Semaille $C$, et al. Enquête nationale de prévalence de l'infection à Chlamydia trachomatis (volet NatChla de l'enquête CSF 2006). À quelles personnes proposer un dépistage? [Survey of the national prevalence of Chlamydia trachomatis infection (NatChla component of the CSF survey 2006). Who should be offered screening?]. Bull Epidemiol Hebd (Paris). 2011;12:160-4. French.

12. French National Institute of Statistics and Economic Studies (INSEE). Pyramide des âges au 1er janvier 2013. [Age pyramid on 1 January 2013]. Paris: INSEE. [Accessed 11 August 2015].
French. Available from: http://www.insee.fr/fr/ppp/basesde-donnees/donnees-detaillees/bilan-demo/fichiers-xls/ pyramide-des-ages-2013.xls

13. French National Institute of Statistics and Economic Studies (INSEE). Recensement de la population de Mayotte, 2007. Population par sexe et âge. [Census of the population of Mayotte, 2007. Population by sex and age]. Paris: INSEE. [Accessed 11 August 2015]. French. Available from: http:// www insee $\mathrm{fr} / \mathrm{fr} /$ insee regions/mayotte/themes/donnees detaillees/rp2007/resultats_detailles/rp2007_population.xls

14. French National Institute of Statistics and Economic Studies (INSEE). Recensement de la population. Mayotte. Populations légales par commune en 2012. [Census of Population. Mayotte. Legal populations by town in 2012]. Paris: INSEE. [Accessed 11 August 2015]. French. Available from: http://www.insee.fr/fr/ insee regions/mayotte/themes/infos/infos61/infos61.xls

15. European Centre for Disease Prevention and Control (ECDC). Sexually transmitted infections in Europe 2012. Stockholm: ECDC; 2014. Available from: http://www.ecdc.europa.eu/en/ publications/Publications/sexually-transmitted-infectionseurope-surveillance-report-2012.pdf

16. Centers for Disease Control and Prevention (CDC). Sexually transmitted disease surveillance 2012. Atlanta: U.S. Department of Health and Human Services; 2013. Available from: http://www.cdc.gov/std/stats12/Surv2012.pdf

17. Public Health Agency of Sweden. Gonorré. [Gonorrhoea]. Stockholm: Folkhälsomyndigheten. [Accessed 11 August 2015]. Swedish. Available from: http://www.folkhalsomyndigheten. se/amnesomraden/statistik-och-undersokningar/ sjukdomsstatistik/gonorre/

18. Public Health Agency of Sweden. Klamydiainfektion. [Chlamydia infection]. Stockholm: Folkhälsomyndigheten. [Accessed 11 August 2015]. Swedish. Available from: http://www.folkhalsomyndigheten.se/amnesomraden/ statistik-och-undersokningar/sjukdomsstatistik/ klamydiainfektion/

19. Public Health England (PHE). STI diagnoses and rates in England by gender, 2004 - 2013. London: PHE. [Accessed 11 August 2015]. Available from: http://webarchive. nationalarchives.gov.uk/20140714084352/http://www.hpa. org.uk/webc/HPAwebFile/HPAweb_C/1215589015024

20. Public Health England (PHE). Number and rates of gonorrhoea diagnoses in England 2003-2012. London: PHE [Accessed 11 August 2015]. Available from: http://webarchive. nationalarchives.gov.uk/20140714084352/http://www.hpa. org.uk/webc/HPAwebFile/HPAweb_C/1281953086913

21. Institut National de Santé Publique du Québec (INSPQ). Portrait des infections transmissibles sexuellement et par le sang (ITSS) au Québec. Année 2013 (et projections 2014). [Portrait of sexually and blood-transmitted infections in Quebec. Year 2013 (and 2014 projections)]. Quebec: INSPQ; 2014. French. Available from: http://www.inspq.qc.ca/pdf/ publications/1920_Portrait_ITSS_2013_Projections_2014.pdf

22. Institut Scientifique de Santé Publique de Belgique (WIVISP). Surveillance des infections sexuellement transmissibles dans la population générale en Belgique et dans les régions. Données de 2012. [Surveillance of sexually transmitted infections in the general population in Belgium and the regions. Data of 2012]. Brussles: WIV-ISP; 2013]. French. Available from: https://www.wiv-isp.be/Documents/WIV-ISP Rapport IST_2012.pdf

23. Public Health England (PHE). Number and rates of chlamydia diagnoses in England, 2003-2012. London: PHE; [Accessed 11 August 2015]. Available from: http://webarchive. nationalarchives.gov.uk/20140505161838/http://www.hpa.org. uk/webc/HPAwebFile/HPAweb_C/1281953081396

24. Farley TA, Cohen DA, Elkins W. Asymptomatic sexually transmitted diseases: the case for screening. Prev Med. 2003;36(4):502-9. Available from: http://dx.doi.org/10.1016/ So091-7435(02)00058-o PMID:12649059

25. Korenromp EL, Sudaryo MK, de Vlas SJ, Gray RH, Sewankambo NK, Serwadda D, et al. What proportion of episodes of gonorrhoea and chlamydia becomes symptomatic? Int J STD AIDS. 2002;13(2):91-101. Available from: http://dx.doi. org/10.1258/0956462021924712 PMID:11839163

26. Jones RB, Rabinovitch RA, Katz BP, Batteiger BE, Quinn TS, Terho $\mathrm{P}$, et al. Chlamydia trachomatis in the pharynx and rectum of heterosexual patients at risk for genital infection. Ann Intern Med. 1985;102(6):757-62. Available from: http:// dx.doi.org/10.7326/0003-4819-102-6-757 PMID:3888022

27. Barry PM, Kent CK, Philip SS, Klausner JD. Results of a program to test women for rectal chlamydia and gonorrhea. Obstet Gynecol. 2010;115(4):753-9. Available from: http://dx.doi. org/10.1097/AOG.ob013e3181d444f6 PMID:20308835

28. Harryman L, Scofield S, Macleod J, Carrington D, Williams $\mathrm{OM}$, Fernandes A, et al. Comparative performance of culture using swabs transported in Amies medium and the Aptima 
Combo 2 nucleic acid amplification test in detection of

Neisseria gonorrhoeae from genital and extra-genital sites: a retrospective study. Sex Transm Infect. 2012;88(1):27-31.

29. European Centre for Disease Prevention and Control (ECDC).

Annual epidemiological report 2014 - sexually transmitted

infections, including HIV and blood-borne viruses. Stockholm: ECDC; 2015 . Available from: http://ecdc.europa.eu/en/ publications/Publications/sexually-transmited-infections-HIVAIDS-blood-borne-annual-epi-report-2014.pdf

30. Institut de la statistique du Québec. Estimation de la population du Québec par groupe d'âge et sexe, au 1er juillet, 2001 à 2014. [Québec population estimate, by age group and sex, on 1 July 2001 to 2014]. Montréal: Institut de la statistique du Québec. [Accessed: 11 August 2015]. French. Available from: http://www.stat.gouv.qc.ca/statistiques/populationdemographie/structure/QC_groupe_age_et_sexe.xlsx

31. Population (Demography, Migration and Projections). Population data. Luxembourg: Eurostat. [Accessed: 11 August 2015]. Available from: http://ec.europa.eu/eurostat/ web/population-demography-migration-projections/ population-data/database 